\title{
Application of the Succession Regulation by German courts — Selected Issues
}

\begin{abstract}
The article discusses the impact of the EU Succession Regulation on the German system of private international law. The change came with some important differences introduced in the text of the Regulation as in comparison to previous German solutions (especially the use of the habitual residence as the main connecting factor instead of nationality), and, as a result of the number of decisions of the CJEU on the Regulation (in particular the Kubicka case).

The paper presents the most important, up-to-date German case-law relating to the EU Succession Regulation. It starts with the general remarks in that regard and continues to discuss judgments covering issues of jurisdiction, applicable law, and the European Certificate of Succession. Three conclusions are drawn therefrom. First, the cases show a general willingness of the courts to cope with the fundamental changes introduced by the Regulation. In particular, the concept of "habitual residence" is applied on the basis of an autonomous interpretation by reference to the case-law of the CJEU on Regulation Brussels IIa. Second, a number of decisions make apparent that the courts are sometimes slow to accept the consequences which flow from the changes brought about by the Regulation, and which oblige to re-consider the German practice in matters of international successions. That applies in particular to the issuing of the European Certificate of Succession. Third, German courts are generally ready to initiate cooperation with the CJEU by formulating preliminary questions (three questions posed by the end of 2019).
\end{abstract}

Keywords: private international law - EU Succession Regulation - case law of German courts - European Certificate of Succession

\footnotetext{
a) Prof., Universität des Saarlandes.
} 


\section{Introduction: Impact of the Succession Regulation on the German system of private international law}

The adoption of uniform provisions on jurisdiction, the applicable law, and the recognition and enforcement of decisions in matters of succession by Regulation No. 650/2012 (to which I will refer hereafter as the Succession Regulation, or "SR") had, unsurprisingly, a decisive impact on the systems of conflict of laws of the EU Member States. Although it was not the most affected, the German conflicts system also underwent important changes. These changes were of two kinds. They resulted, firstly, from certain guiding principles enacted in the Regulation itself, and, secondly, from a number of rulings of the Court of Justice of the European Union (hereafter: "CJEU"). The most far-reaching change generated by the Regulation was the choice of the habitual residence of the deceased as the general connecting factor for the purposes of determining both jurisdiction and applicable law (Articles 4 and 21). It replaced the long-standing German conflicts rule according to which the nationality of the deceased was the decisive factor for the determination of the lex successionis. A further change resulted from the possibility for the testator to choose, instead of the law of the habitual residence, the law of the State whose nationality he possesses at the time of making the choice or at the time of death as the law governing his succession (Article 22). The hitherto applicable rule in Germany only allowed the choice of German law for the succession to immovables situated in Germany ${ }^{1}$. So far for the most important changes brought about by the Regulation itself. It may be mentioned in that context that another general principle of the Regulation, according to which the applicable law is to govern the succession as a whole, did not come as a novelty, as German conflicts law adhered since long to the principle of Nachlasseinheit and, in particular, did not distinguish, as regards the scope of the applicable law, between succession to movables and to immovables.

In addition to the aforementioned changes, German conflicts law in matters of succession was affected by a number of decisions of the CJEU on the Regulation, of which I will mention three. The first ruling, given in the Polish-German case of Kubick $a^{2}$, concerned the recognition in Ger-

${ }^{1}$ See the former Article 25(2) of the Introductory Law to the (German) Civil Code (EGBGB).

${ }^{2}$ CJEU, 12.10.2017, C-218/16 Kubicka; cf. the comment by Thorn, Lasthaus, "Praxis des Internationalen Privat- und Verfahrensrechts" (hereafter: "IPRax") 2019, p. 24; Weber, "Deutsche Notar-Zeitschrift" 2018, p. 16. 
many of the material effect of a legacy "by vindication" provided for by the law governing succession (in the instant case, Polish law). Although German law only provides for legacies "by damnation"3, the CJEU ruled that where immovable property situated in Germany is the object of a legacy "by vindication", Germany has to recognise the direct material effect provided for by the Polish lex successionis. In its judgment the CJEU insisted on the principle of unity of the succession and stated that "to accept that Article 1(2)(l) of Regulation No 650/2012 allows the acquisition of ownership of an asset by legacy 'by vindication' to be excluded from the scope of that regulation would lead to the fragmentation of the succession, which is incompatible with the wording of Article 23 of the same regulation and with its objective"4. The second ruling of the CJEU that has to be mentioned likewise obliged Germany to depart from an accepted principle of German private international law. It related to the characterisation of a provision of German substantive law situated at the intersection between succession and matrimonial property law. That provision, $\S 1371$ (1) of the Civil Code (BGB), concerns the share of the inheritance of the surviving spouse if the spouses lived in the property regime of community of accrued gains (Zugewinngemeinschaft). It provides that at the death of a spouse "the equalisation of the accrued gains is effected by increasing the share in the inheritance on intestacy of the surviving spouse by one quarter". Whether that provision is part of inheritance law or matrimonial property law was highly controversial in German private international law until the Bundesgerichtshof (BGH) ruled in 2015 that the "flat-rate equalisation" of accrued gains provided for in $\S 1371(1)$ BGB was to be classified as "purely matrimonial property law". For the $\mathrm{BGH}$, the purpose of the provision was decisive: to dispose of the matrimonial property regime as a special arrangement of the property of

${ }^{3}$ Before the European Court, the German government referred to the explanatory memorandum of the German draft law on international succession law and amending the provisions governing the certificate of succession and other provisions (Gesetzesentwurf der Bundesregierung, Bundestag-Drucksache 17/5451 of 4 March 2015) which provides that it is not obligatory, in the context of Regulation No 650/2012, for German law to recognise a legacy "by vindication" on the basis of a will drawn up according to the law of another Member State.

${ }^{4}$ Para. 57, emphasis added.

${ }^{5}$ BGH 13.5.2015 - IV ZB 30/14, BGHZ 205, 289, "Zeitschrift für das gesamte Familienrecht" (hereafter: "FamRZ") 2015, p. 1180 with a comment by Mankowski. In that case, the inheritance share of the surviving spouse was to be determined in accordance with Greek law and amounted to one quarter; the spouses had lived in the matrimonial property regime of the community of accrued gains pursuant to German law, so that the increase of the statutory inheritance portion by one quarter pursuant to $§ 1371(1)$ BGB was effected by virtue of matrimonial property law. 
the spouses, not to allow the survivor to participate in the deceased's property by virtue of his attachment to the deceased. The increase in the statutory share of the inheritance was conceived by the legislature as a special type of equalisation of gains, and that function was not called into question by the fact that it was realised "by way of inheritance law". It was no surprise that the analogous issue presented itself under the Succession Regulation: Does a provision like §1371(1) BGB fall under the concept of succession upon death as understood by the Regulation, or is it excluded therefrom because it concerns a question "relating to matrimonial property regimes" (Article 1(2)(d))? Contrary to expectations in legal literature, which had predominantly welcomed the matrimonial property characterisation by the BGH, the CJEU decided that $\S 1371(1)$ BGB had to be characterised as belonging to the law of succession. ${ }^{6}$ By contrast to the $\mathrm{BGH}$, the Court of Justice, in agreement with the Opinion of Advocate General Szpunar, saw the "main purpose" of this provision not in the division of property between the spouses or in the termination of the matrimonial property regime, but "in the determination of the portion of the inheritance which belongs to the surviving spouse in relation to the other heirs" . Such a provision "principally" concerns succession to the estate of the deceased spouse and not the division of assets between spouses or the termination of the matrimonial property regime ${ }^{8}$. The consequence of this is, in particular, that information on the increased share of the inheritance pursuant to §1371(1) BGB has to be included in the European Certificate of Succession. The CJEU adds that the objectives pursued by this certificate would be significantly compromised if it did not "include full information relating to the surviving spouse's rights regarding the estate" 9 . Following the CJEU's ruling the application of the Succession Regulation is undoubtedly facilitated; moreover the effet utile of the European Certificate of Succession is ensured. With the characterisation of $\S 1371(1)$ BGB as belonging to inheritance law, the CJEU did not, however, eliminate the problem of the interfaces between inheritance law and property law, but merely reversed its signs. Since the "matrimonial property quarter" presupposes that the spouses have lived under the property regime of the community of accrued gains, a "clean" solution presupposes that German law governs both the suc-

${ }^{6}$ CJEU, 1.3.2018, C-558/16 Mahnkopf, "FamRZ” 2018, p. 632 with a comment by Fornasier.

${ }^{7}$ Para. 40 of the judgment.

8 This statement is also supported by the fact that according to $\S 1371(1)$ BGB the increase in the statutory share of the inheritance by a quarter is independent of whether the spouses have made any gains at all.

${ }_{9}$ Para. 43 of the judgment. 
cession and the property regime. If the succession and property regimes diverge, problems of coordination and adaptation arise as before.

The third ruling of the CJEU which had an important impact on the German law and practice in matters of international successions concerned the scope of Article $4 \mathrm{SR}$ on the general jurisdiction of the courts of the Member State in which the deceased had his habitual residence "to rule on the succession as a whole". Does that provision, which applies for the issuing of European Certificates of Succession (ECS), also apply for the issuing of national certificates of succession (which are not precluded by the ECS)? The background to that question was a provision of German law relating to the (international and territorial) jurisdiction of courts in matters of succession, ${ }^{10}$ which stipulates that where the deceased did not have his habitual residence in Germany, the Amtsgericht Schöneberg in Berlin shall have jurisdiction if the deceased was a German national or if part of the estate is located in Germany. The CJEU ruled that Article $4 \mathrm{SR}$ precluded national legislation such as the German provision ${ }^{11}$. In agreement with A-G Szpunar, the Court understood Article 4 as applying to all proceedings in matters of succession taking place before the courts of the Member States irrespective of whether decisions were given in contentious or non-contentious proceedings. Thus the provision covers also procedures that do not lead to the adoption of a judicial decision as defined by the Regulation. Again, the Court emphasised the principle of the unity of the succession, to which it added that the rules of the Regulation are devised so as to ensure that the court having jurisdiction will, in most situations, have to apply its own law. Clearly, allowing the courts of the Member States to issue national certificates of succession when they have jurisdiction according to national law bears the risk that the Gleichlauf-principle is not respected and that contradictory decisions relating to the succession may be given in the Member States. The CJEU's ruling puts an end to the long-standing practice of German courts to issue (national) certificates of succession under foreign law relating, and limited, to assets located in Germany (gegenständlich beschränkte Fremdrechtserbscheine). At the same time, the ruling strengthens the role of the ECS, although national certificates of succession may still be issued by the courts or a competent authority in another Member State having jurisdiction under Article 4 SC.

${ }^{10} \S 343(3)$ of the law on proceedings in family matters and matters subject to noncontentious proceedings (FamFG). Whether that provision was overruled by Article 4 SC was a matter of controversy when the German implementing legislation was prepared, see the details reported by Fornasier, "FamRZ" 2018, p. 1265.

${ }^{11}$ CJEU, 21.6.2018, C-20/17 Oberle, "FamRZ" 2018, p. 1262 with a comment by For nasier. 


\section{German case-law on the Succession Regulation - general remarks}

Decisions of German courts on the Succession Regulation have become known since 2016. However, there are no reliable figures on the number of cases decided under the SR. As judgments or orders of first instance courts have rarely been made public, most of the case-law publicly available emanates from higher regional courts, the Oberlandesgerichte (OLG), which decide on appeal ${ }^{12}$. The first and, so far, only decision of the Federal Court of Justice, the Bundesgerichtshof $(\mathrm{BGH})^{13}$, has been delivered in July 2019 ${ }^{14}$. Most of the decisions have been published in legal periodicals, some only in the juris database. The decisions have mainly been given in non-contentious proceedings relating to the issuing of certificates of succession, either European or national. They frequently address points of jurisdiction, while questions relating to the applicable law are less discussed. The following paragraphs will present a limited number of decisions which deserve particular attention.

\section{Jurisdiction}

In matters of jurisdiction, the habitual residence of the deceased the main connecting factor for the determination of both the jurisdiction of courts and the applicable law - had to be frequently assessed by the courts. Where that concept is discussed in some depth, the courts refer to Recitals 23 and 24 of the SR and to the case-law of the CJEU on Regulation Brussels IIa. ${ }^{15}$ On the basis that it is an autonomous concept of EU law, the courts are often paraphrasing the requirement, formulated in Recital 23, that they have to "make an overall assessment of the circumstances of the life of the deceased during the years preceding

${ }^{12}$ For the present report, approximately 20 appeal decisions have been considered.

${ }_{13}$ The BGH decides on further appeals (Revision or Rechtsbeschwerde), which require that leave to appeal has been granted by the OLG. In contentious proceedings, the decision not to grant leave to appeal may itself be appealed; by contrast, no such appeal lies if leave to appeal is not granted in non-contentious proceedings, cf. § 61 FamFG.

${ }^{14}$ BGH, 10.7.2019, infra, fn. 24.

15 The case-law referred to includes in particular the judgments in the "A" case (2.4.2009, C-523/07) and the Mercredi case (22.12.2010, C-497/10 PPU). For a comprehensive discussion of the concept see Kurth: Der gewöhnliche Aufenthalt in Art. 4, 21 Abs. 1 EuErbVO, 2017, reviewed by Mankowski, "FamRZ" 2018, p. 672. 
his death and at the time of his death, taking account of all relevant factual elements, in particular the duration and regularity of the deceased's presence in the State concerned and the conditions and reasons for that presence. The habitual residence thus determined should reveal a close and stable connection with the State concerned taking into account the specific aims of [the] Regulation." In that context, two scenarios of more general interest have been discussed by the courts. The first concerns the determination of the habitual residence of a cross-border commuter. In a case decided by the Berlin Kammergericht in $2016^{16}$, the deceased, a German national, had, after retirement, moved to Poland where he had rented a flat close to the German border. He maintained an apartment in his daughter's house in Berlin but, apparently, never stayed there. Anyhow, he continued his former business as a construction entrepreneur on the German side of the border while always returning to his place in Poland. It appeared that his family and social contacts in Berlin were not disrupted and continued as before; he also kept his German bank accounts. His ties to Poland were tenuous. He did not speak Polish and had no contacts in Poland, with the exception of casual conversations with the pastor of the local church, who spoke German. On these findings, the Kammergericht concluded that the centre of the life interests (Mittelpunkt des Lebensinteresses) of the deceased had not changed after retirement and that his habitual residence continued to be in Germany. Although that conclusion seems arguable, it has been rightly remarked that it needs particularly strong elements to rebut the presumption, recalled by a German legal scholar, that the habitual residence is "where one goes to sleep"17. In the rather atypical case at hand those elements were probably present. But take the case of modern European nomads: a French couple working in Luxembourg with an international organisation, who rented an apartment on the German side of the Moselle where they return every night. Even if they do not speak German, and although they may go to Paris over the weekend on a regular basis, the presumption based on the German place of abode would point to an habitual residence in Germany.

Another scenario relates to the situation of German pensioners spending their life after retirement out of Germany, preferably in Spain, while keeping at least part of their family and social relations in Germany. The determination of the centre of life of the deceased may be difficult in those cases. As the courts consider "habitual residence" to be a fac-

${ }_{16}$ Kammergericht, 26.4.2016, "FamRZ" 2016, p. 1203 with a comment by Mankowski, "IPRax" 2018, p. 72 with a comment by Martiny, p. 29.

${ }^{17}$ Mankowski, "FamRZ" 2016, p. 1204. 
tual concept, its determination requires them in the first place to bring together the "factual elements" mentioned in Recital 23 of the $\mathrm{SR}^{18}$. The evaluation of those elements is left to the discretion of the court, and it does not come as a surprise that in a given case the first instance court and the appellate court come, with equal conviction, to opposite results ${ }^{19}$. In that context, the courts emphasise at times that the points to be taken into account include not only objective but also subjective elements, in particular the intention of the deceased to stay and to remain in a given place. ${ }^{20}$ To that end the courts often cite commentators of the Succession Regulation who refer to the CJEU's judgment in the Mercredi case where the Court said that "[b]efore habitual residence can be transferred to the host State, it is of paramount importance that the person concerned has it in mind to establish there the permanent or habitual centre of his interests, with the intention that it should be of a lasting character. Accordingly, the duration of a stay can serve only as an indicator in the assessment of the permanence of the residence, and that assessment must be carried out in the light of all the circumstances of fact specific to the individual case ${ }^{21}$." The Mercredi case concerned the interpretation of Article 8 of Regulation Brussels IIa. There are valid reasons to transpose the statement of the European Court, mutatis mutandis, to the interpretation of the concept of habitual residence in the Succession Regulation. But this is far from being acte clair, and a reference to the CJEU would seem appropriate before reaching that conclusion.

Particular problems arise where the deceased died in a hospital or a nursing home in a far-away country (where he had been brought by relatives because the cost of long-term care is lower than in European countries). What elements are required in order to conclude that the ha-

18 See Oberlandesgericht Hamburg, 16.11.2016, "FamRZ” 2017, p. 568; Oberlandesgericht Köln, 4.07.2018 - $2 \mathrm{Wx} 222 / 18$, juris.

19 See, for example, Oberlandesgericht Hamm, 2.01.2018, IPRax" 2019, 151 with a critical comment by Kurth, p. 123), a case where the deceased, who had died in Spain, had lived in that country for many years, inter alia during his second marriage. That marriage was followed by a third one in Germany, but the deceased had separated from his wife and gone again to Spain. However, he was still a registered resident in Germany and his mail was not forwarded to Spain; he received medical treatment in Germany, and allegedly wished to return there. While the first instance court had concluded that the habitual residence of the deceased was in Spain, the OLG Hamm came to the opposite result.

${ }^{20}$ Obviously, the existence of the animus manendi is often inferred from objective elements and thus again left to the discretion of the courts. In the case referred to above, the Oberlandesgericht emphasised that the deceased had lacked the intention to stay permanently in Spain. A certain "homeward trend" may have guided that conclusion of the German court.

${ }^{21}$ CJEU, 22.12.2010, C-497/10 PPU Mercredi, para. 51 emphasis added. 
bitual residence of the deceased has been transferred to that country? According to the Oberlandesgericht München ${ }^{22}$ the intention of the deceased to stay and to remain in the host State must be established also in these cases. On the basis that habitual residence is a factual concept, the court held that the animus manendi does not require full legal capacity, but that the person concerned must be in a position to express his intentions. The court also emphasised that there can be no legal representation of that person in the context of establishing a habitual residence; otherwise, the legal representative would be in a position to choose the applicable law to the succession of the person concerned. Clearly, also as regards that issue a reference to the CJEU would have been appropriate.

\section{Applicable law}

There have been so far only a few decisions in which the choice-oflaw rules of the Succession Regulation have been discussed by German courts. In the case decided by the Bundesgerichtshof in July, 2019, those rules had to be applied pursuant to the transitional provisions of Article $83 \mathrm{SR}^{23}$. The deceased, a woman of German nationality who died in 2017, left two dispositions of property upon death, an agreement as to succession (Erbvertrag) concluded in 1998, and a will made in 2016; both instruments had been made in Germany before a notary. The deceased had concluded the agreement with her then life companion, an Italian national who had lived in Germany since 1986. In the agreement they appointed each other as sole heirs; their two children were to be heirs of the surviving party. They also declared that their succession was to be governed in every respect by German law. In 1998, however, such a choice was not permitted under German conflicts law ${ }^{24}$. In 2016, after their relationship had come to an end, the woman made a will in which she appointed as heirs her unborn grand-children and, in case that no grand-children should be living at the time of her death, another person, the appellant in the instant case. After her death, her former companion claimed to be her sole heir arguing that the 2016 will was null and void because it violated the 1998 agreement. That claim was opposed by the presumptive heir, who argued that the 1998 agreement was

22 Oberlandesgericht München, 22.3.2017, “FamRZ” 2017, p. 1251.

${ }^{23}$ BGH, 10.7.2019 - IV ZB 22/18, "FamRZ" 2019, p. 1561, with a comment by von Bar. I am grateful to Dr Carl-Friedrich Nordmeier for his comments on this decision.

${ }^{24}$ It was, however, allowed under Italian law in the relevant time, see the following footnote. 
invalid as its conclusion was governed, as far as the companion of the deceased was concerned, by Italian law according to which a disposition of property with binding effect is invalid because it limits the testamentary freedom of the testator ${ }^{25}$. The Bundesgerichtshof upheld the claim of the deceased's companion. Starting from Article 83(2) SR, the court held that according to Article 25(3) SR the parties to the 1998 agreement had validly chosen German law to govern the agreement as that provision permits the parties to choose the law of a State of which either of the parties is a national. German law, validly chosen, allows agreements as to succession with binding effect and provides that a subsequent disposition of property upon death is invalid to the extent that it impairs the rights of the beneficiary of the agreement ${ }^{26}$. The court then discusses the appellant's argument that the retroactive application of the conflict rules of the SR - which leads to the validity of the initially invalid choice of German law - violates the principles of legal certainty and non-retroactivity recognised by EU law and German constitutional law. However, according to the court, these principles apply only to cases of authentic retroactivity, that is, cases where the provision in question is designed to control a situation which is already completed or "closed" (abgeschlossen) because it has produced its effects in the past. In the present context that would be the case if the testator had died, and the succession had been opened, before the applicability of the Succession Regulation ${ }^{27}$. By contrast, the retroactive effect of Article 83(2) SR is permitted - as in-

${ }^{25}$ See Article 458 Codice civile. It is, however, open to doubt whether Italian law was applicable at the time the agreement was made. Under German conflicts law in force in 1998 the admissibility of the agreement was governed for each party by his or her national law, that is, German law and Italian law in the present case. However, the reference to Italian law included the rules of private international law, and according to Article 46(2) of the Italian Act on Private International Law (Law No 218 of 1995) a person could choose as the law to govern his succession, instead of the lex patriae which would normally apply, the law of the State of his habitual residence. Thus, in the instant case, the choice of German law by the Italian companion of the deceased was valid and lead to a renvoi to German law. As a result, as German law applied in any case to the deceased because of her German nationality, the admissibility of the 1998 agreement was to be assessed solely under that law.

${ }^{26}$ See $\S 2289$ BGB.

${ }^{27}$ In a case decided by the Oberlandesgericht Schleswig (25.4.2016 - $3 \mathrm{Wx} 122 / 15$, "FamRZ" 2016, 1606) the presumptive heir of the deceased, a national of Poland who had died in 2014, argued that the German legislator had ordered the retroactive application of the SR so as to cover the succession of the deceased. That is rightly denied by the court: the new Article 25 of the Introductory Law to the German BGB, which became applicable on August 17, 2015, provides for the analogous application of Chapter III of the SR in matters of succession not covered by the Regulation. A retroactive application of the SR itself is of course not intended. 
authentic retroactivity - where the testator died on or after August 17, 2015 , because the succession is opened only at that time. The court refers to the objectives of the transitional rules which tend not only to ensure the validity of dispositions of property made before the applicability of the Regulation but also to permit invalid dispositions to become valid. The court detects here a favor testamenti which amounts to a rule of validation, whereas it is not prepared to protect a party's expectations as to the invalidity of a previous disposition of property upon death.

In a case before the Amtsgericht Hamburg-Wandsbeck decided in $2018^{28}$ the court had to rule on the interpretation of a joint will that had been made by the deceased and her husband in Chicago in 1967. Both were German nationals who had emigrated to the Unites States. The will was typewritten and signed by the couple and three witnesses. It disposed that upon the death of one of the spouses their property "shall be held by the survivor to use the same as the survivor may see fit, and to have and to hold to the said survivor, survivor's heirs and assigns forever". The husband died in the United States in 1968. The wife died when the Succession Regulation already applied. Before the Hamburg court, a dispute about the heritage arose between the siblings of the wife and other relatives. The court held that the succession to the deceased was governed by the Regulation according to Article 83(1) SR. The formal validity of the joint will made in 1967 is then assessed according to the 1961 Hague Convention on the form of wills (to which Article 75(1) SR refers). The court applies Illinois law as the law of the place where the testamentary disposition was made, and affirms the formal validity of the will according to $\S 43$ of the Illinois Probate Act of 1939, as applicable in 1967. The court then determined the law applicable to the interpretation of the will, which was at the centre of the dispute. As according to Art. 26(1)(d) SR the interpretation pertains to the substantive validity of the will, the court had to determine the law applicable in that respect. Applying Art. 83(3) and Art. 24(1) SR, the court refers to Illinois law as the law of the habitual residence of the testator at the time the will was made which, according to Art. 21 SR, would have been applicable to the succession if the testator had died on the day on which the disposition was made. Thus Illinois law as the hypothetically applicable law governs also the interpretation of the will. Having reached that conclusion, the court, in an obiter dictum, expresses doubts as to its result. It notes that under the German conflict rules in force in 1967, the interpretation of the will of the testator would have been governed by German law as the

${ }^{28}$ Amtsgericht Hamburg-Wandsbeck, 17.05.2018, "FamRZ" 2018, p. 1274 with a critical comment by Ludwig. 
law governing the succession because of the nationality of the couple. That situation changed with the applicability of the SR in 2015. According to the court, the change of the applicable law seems problematic as the testator had relied since 1967 on the applicability of German law. The court then looks for a possibility to apply German law under the rules of the SR. It envisages to apply Art. 21(2) SR, which provides, by way of exception, for the application of the law of another State than that of the habitual residence if the deceased was manifestly more closely connected with that other State. Referring to the German nationality of the deceased, her lasting connections with Germany, and the fact that the beneficiaries of the will were in Germany, the court seemed disposed to conclude that the deceased is more closely connected with Germany than with Illinois. However, it did not decide the issue as the interpretation of the will according to German law would have yielded the same result as the interpretation according to the law of Illinois.

As far as the scope of the applicable law is concerned, a decision of the Oberlandesgericht Saarbrücken applying the reasoning of the CJEU's ruling in Kubicka deserves mentioning ${ }^{29}$. A resident of France died in 2016, without leaving a will. His estate included an apartment in Germany. French law governed the succession, and heirs on intestacy were the wife of the deceased, and descendants. The wife applied to the competent German court for a rectification of the land register (Grundbuch) where the deceased was registered as owner of the apartment. She presented a European Certificate of Succession, issued by a notary in Paris, according to which, upon the partition of the estate, she was entitled to $5 / 8$ as full property, and 3/8 as usufruct, and asked that her position be registered accordingly. The first instance court dismissed the application. As regards the registration of the usufruct, that court noted that a transfer of title by the heirs was necessary because the usufruct had no effect in rem for the purposes of registration in the German land register. On appeal that decision was overturned. Referring to the CJEU's judgment in Kubicka ${ }^{30}$, the appellate court held that where the lex successionis provided for the direct material effect of a legacy ("legacy by vindication") that effect was to be recognised also in a Member State whose law provides only for legacies "by damnation", which only have effect in personam. That principle applied to the usufruct of the surviving spouse according to French law. Accordingly, the registration of the usufruct did not require a consensual transfer of title as the wife acquired

${ }^{29}$ Oberlandesgericht Saarbrücken, 23.5.2019 - 5 W 25/19, "FamRZ" 2019, p. 1569.

${ }^{30}$ Supra, fn. 3. 
that right with direct effect ex lege upon the death of her spouse ${ }^{31}$. This meant that the German land register was no longer correct and had to be rectified. In order to prove the incorrectness of the land register it suffices according to the court that the beneficiary presents a European Certificate of Succession which contains the information about the right in question. The court points to Art. 63(2)(b) SR, according to which the ECS may be used to demonstrate "the attribution of a specific asset ... of the estate to the heir(s) or ... the legatee(s) mentioned in the Certificate". That Certificate must be accepted as proof for the purposes of registration of an asset of the estate. The court rejects the argument put forward by German authors that the court has still to verify whether according to the lex successionis the acquisition of the right mentioned in the certificate took place with immediate effect. The court refers to Article 69(2)(2) SR, which provides that the person mentioned in the Certificate as heir or legatee is "presumed to have the status"32 and hold the right therein mentioned "with no conditions and/or restrictions being attached to [the right in question] other than those stated in the Certificate". However, that presumption may be rebutted, and the authority to which the Certificate is presented is entitled to verify its content "like in the case of national certificates of succession" where there are doubts as to its correctness. Finally, the court gives detailed instructions to the lower court how to proceed in the case at hand. Clearly, the elaborated reasoning of the court shows its consciousness that the situation under the Succession Regulation is dramatically different from the hitherto applicable rules and overturns the long-standing German practice in matters of administering successions governed by foreign law.

\section{The Furopean Certificate of Succession}

In the cases just mentioned the German courts had to deal with the administration of estates where foreign law governed the succession. Another line of cases shows that comparable problems may arise where German law is applicable in that respect. A number of decisions delivered by the appellate courts in Nuremberg and Munich concerned cases where the estate of the deceased included immovable property situated in other Member States. In these cases, in order to register the acquisi-

${ }^{31}$ See also Jacoby: Die Rechte des überlebenden Ehegatten und das europäische Nachlasszeugnis in den deutsch-französischen Beziehungen. „GPR - Zeitschrift für das Privatrecht der Europäischen Union" 2018, p. 303.

${ }^{32}$ Emphasis added. 
tion of the property by the heirs the foreign registration authority asked for a certificate of succession where the particular immovable was identified. As German law adheres to the principle of Universalsukzession ${ }^{33}$ according to which the succession as a whole, or a share thereof, passes to the heir(s), a national certificate of succession (Erbschein), which demonstrates the status of the heir(s), never mentions single assets of the estate. Does that principle apply also to the European Certificate of Succession? In a typical case concerning immovable property in Austria, the Munich Court of Appeals refused the application of the sole heir to have the property mentioned in the ECS for the purposes of registration in Austria $^{34}$. The court emphasised that the principle of universal succession excludes any mention of individual assets in the ECS. It then turned to Art. 63(2)(b) SR, which provides that the Certificate may be used to demonstrate the attribution of specific assets to the heirs, and Art. 68(l) SR, according to which the Certificate may contain a list of assets for any given heir. According the court, those provisions only apply where individual assets are attributed to the heir with immediate effect ex lege, like in the case of the partition of an estate according to foreign law (legacies by vindication are not mentioned by the court). As German law provides for the attribution of the succession as a whole the said provisions were not applicable. The court follows herewith the interpretation of the provisions in cases previously decided by the Nuremberg Court of Appeals ${ }^{35}$. However, that case-law has rightly been criticised by German legal scholars ${ }^{36}$, who emphasise that nothing in the wording of Art. 68(l) and $(\mathrm{m}) \mathrm{SR}$ warrants the narrow interpretation advanced by the Nuremberg and Munich courts. On the contrary, the objectives and the effet utile of the ECS to facilitate the administration of successions in the EU are better served if individual assets are mentioned in the Certificate also in cases where the lex successionis follows the principle of universal succession. Actually, a broader interpretation of the provisions of the

${ }^{33}$ As opposed to Singularsukzession or Einzelrechtsnachfolge.

${ }_{34}$ Oberlandesgericht München, 12.09.2017, "FamRZ" 2018, p. 142. It appears however that the position of the lower Austrian courts has been overruled by the Austrian Supreme Court (Oberster Gerichtshof [OGH]) who is ready to accept a ECS concerning successions under German law where immovables in Austria are not mentioned, see OGH, 29.08.2017 - 5 Ob 108/17v, "FamRZ" 2018, p. 635, and OGH, 15.5.2018 - 5 Ob 35/18k, EvBl 2018/151.

${ }^{35}$ See Oberlandesgericht Nürnberg, decisions of 5.4.2017 ("FamRZ" 2018, p. 143, "IPRax" 2019, p. 327) and 27.10.2017 ("IPRax" 2019, p. 328).

${ }^{36}$ See in particular Nordmeier, Die Aufnahme einzelner Nachlassgegenstände in das Europäische Nachlasszeugnis - zum durch den Todesfall bedingten Rechtserwerb und zur Reichweite der Art. 68 lit. l und m EuErbVO. "IPRax" 2019, p. 306. 
SR appears to be in line with the CJEU's decisions in Kubicka ${ }^{37}$ and Mahnkop ${ }^{38}$ where the objectives of the ECS were referred to in order to support the findings of the Court.

However, it has to be kept in mind that individual rights or assets may be mentioned in the ECS only if they have been attributed to the beneficiary successionis causa. Rights, interests and assets "created or transferred otherwise than by succession" are excluded from the scope of the SR according to Art. 1(2)(g). That principle was applied by the Nuremberg Court of Appeals ${ }^{39}$ in a case where the deceased and her husband were joint owners of an apartment in Austria. According to the relevant Austrian legislation the surviving spouse acquires full ownership by way of accrual (Anwachsung) upon the death of the other spouse ${ }^{40}$. According to the court, such acquisition is comparable to the effects of a joint tenancy ${ }^{41}$ and takes place otherwise than by succession. It is thus excluded from the Regulation, and the right of ownership acquired by way of accrual may not be mentioned in the ECS. Anyhow, in order to define the conditions under which individual assets of the estate may be mentioned in the ECS under Art. 68 SR, in particular in cases where such mention is necessary for the purposes of registration, a reference to the CJEU would seem required in an appropriate case.

\section{Concluding remarks}

It is obviously too early to draw solid conclusions from the German case-law under the Succession Regulation delivered so far. The number of reported cases is small, and decisions merely applying the provisions of the Regulation are of limited interest. However, three tentative findings may be formulated. First, the cases presented show a general willingness of the courts to cope with the fundamental changes introduced by the SR. They also show that the courts are ready to interpret key concepts of the Regulation in a European way. In particular the concept of "habitual residence" is applied on the basis of an autonomous interpretation by reference to the case-law of the CJEU on Regulation

\footnotetext{
${ }^{37}$ Supra, fn. 2.

${ }^{38}$ Supra, fn. 6.

39 Oberlandesgericht Nürnberg, 25.4.2017, "IPRax" 2019, 328.

$40 \S 14$ Wohnungseigentumsgesetz.

${ }^{41}$ Expressly mentioned in the German version of Article 1(2)(g) SR.
} 
Brussels IIa, and mindful of a coherent application of the concepts of European private international law. Second, a number of decisions make apparent that the courts are sometimes slow to accept the consequences which flow from the changes brought about by the Regulation, and which oblige to re-consider the German practice in matters of international successions. That applies in particular to the issuing of the European Certificate of Succession. In that respect the provisions of the Regulation are sometimes viewed under the strict rules governing the issuing of the German Erbschein. The third finding concerns the role of the European Court. German courts have already triggered three preliminary rulings on the interpretation of the SR. In the cases presented herein a number of issues have become apparent which deserve to be referred to the CJEU. They concern, inter alia, elements of the concept of habitual residence in Art. 4 and Art. 21 SR, and the content of the ECS. Clearly, a further contribution of the European Court would be welcome in order to facilitate, and harmonise, the application of the Regulation in the Member States.

\section{References}

Fornasier M.: A comment to decision of CJEU, 1.3.2018, "Zeitschrift für das gesamte Familienrecht" 2018, pp. 624-632.

Fornasier M.: A comment to decision of CJEU, 21.6.2018, "Zeitschrift für das gesamte Familienrecht" 2018, pp. 1265-1266.

Jacoby E.: Die Rechte des überlebenden Ehegatten und das europäische Nachlasszeugnis in den deutsch-französischen Beziehungen, "GPR - Zeitschrift für das Privatrecht der Europäischen Union” 2018, pp. 303-308.

Kurth S.: Der gewöhnliche Aufenthalt in Art. 4, 21 Abs. 1 EuErbVO, 2017. Einzeldarstellung, 2018.

Mankowski P.: A comment to decision of BGH 13.5.2015, "Zeitschrift für das gesamte Familienrecht" 2015, pp. 1180-1183.

Mankowski P.: A review of Der gewöhnliche Aufenthalt in Art. 4, 21 Abs. 1 EuErbVO, 2017. "Zeitschrift für das gesamte Familienrecht" 2018, p. 672.

Mankowski P.: A comment to decision of Kammergericht Berlin, 26.4.2016, "Zeitschrift für das gesamte Familienrecht" 2016, p. 1203.

Nordmeier C.F.: Die Aufnahme einzelner Nachlassgegenstände in das Europäische Nachlasszeugnis - zum durch den Todesfall bedingten Rechtserwerb und zur Reichweite der Art. 68 lit. l und $m$ EuErbVO. "IPRax" 2019, pp. $306-312$. 
Thorn K., Lasthaus C.: A comment on Kubicka, "Praxis des Internationalen Privat- und Verfahrensrechts" 2019, pp. 24-30.

Weber J.: Kubicka und die Folgen: Vindikationslegate aus Sicht des deutschen immobiliarsachenrechts, "Deutsche Notar-Zeitschrift: Verkündungsblatt der Bundesnotarkammer" 2018 n 1, pp.16-32. 